\title{
Fry and Rf $/ \phi$ strain methods constraints and fold transection mechanisms in the NW Iberian Variscides
}

\author{
A. Soares ${ }^{a}$, R. Dias ${ }^{\text {a, b, c, * }}$ \\ ${ }^{a}$ Research Laboratory of Industrial and Ornamental Rocks (LIRIO), University of Évora, Portugal \\ ${ }^{\mathrm{b}}$ Earth Sciences Institute (ICT), Pole of the University of Évora, Rua Romão Ramalho, $n^{\circ}$ 59, 7000-671 Évora, Portugal \\ ${ }^{\mathrm{c}}$ Gesciences Department, Sciences and Techology School, University of Évora, Portugal
}

\section{A R T I C L E I N F O}

\section{Article history:}

Received 4 April 2015

Received in revised form

21 June 2015

Accepted 3 July 2015

Available online 11 July 2015

\section{Keywords:}

Transected folds

Variscan Iberia

Central Iberian Zone

Fry versus $\mathrm{Rf} / \phi$ method

Strain partitioning

\begin{abstract}
A B S T R A C T
Apúlia is a small Portuguese sector in NW of Central-Iberian Zone, that have been deformed in a noncoaxial sinistral transpressive regime during the first and main Variscan tectonic event $\left(D_{1}\right)$. This deformation give rise to a major NW-SE anticline, where the $\mathrm{S}_{1} \mathrm{~N}-\mathrm{S}$ cleavage transect the inverted short NE limb; two and three-dimensional strains analysis have been done in the low metamorphic grade Ordovician quartzites of this limb using Fry and Rf $/ \phi$ methods. The data show that most deformation was due to intergranular deformation mechanisms. The intragranular deformation leading to the distortion of strain markers and to cleavage was very incipient and a latter event in the $D_{1}$ phase. The apparent plane strain ellipsoids (if no volume change is assumed) related to the intragranular mechanisms contrast with the more prolate strain ellipsoids related to the bulk deformation of Apúlia Quartzites. This constrictional bulk strain fabrics are characteristic of the sinistral transpressive regimes dominant in the northern sectors of the Central-Iberian Zone.
\end{abstract}

๑) 2015 Published by Elsevier Ltd.

\section{Introduction}

The understanding of the tectonic events that have been active in a region is crucial for establishing the geodynamical evolution of that region. The succession of such events is usually done by the study of the interference between tectonic structures. However, often the observed deformation, although induced by a long lasting orogenic process, cannot be ascribed to independent tectonic pulses because of the lack of superposition between individual structures. This could happen either in coaxial or non-coaxial tectonic events. Sometimes the continuity of the deformation process can be highlighted by the evolution of particular structures like echelon veins, (Hancock, 1972), inclusion trails in porphyroblasts (Bell and Johnson, 1989), pressure shadows (Etchecopar and Malavieille, 1987) or boudins (Lacassin et al., 1993). Nevertheless most common structures, like folds and cleavage, are not easy to interpret because similar geometries could be obtained by different mechanisms (Ramsay, 1967; Ramsay and Huber, 1983; Twiss and Moores,

\footnotetext{
* Corresponding author. Earth Sciences Institute (ICT), Pole of the University of Évora, Rua Romão Ramalho, n 59, 7000-671 Évora, Portugal.

E-mail addresses: asoares@estremoz.cienciaviva.pt (A. Soares), rdias@uevora.pt (R. Dias).
}

1992). Moreover, crustal-scale deformation is usually heterogeneous with strain partitioning between high strain shear zones and surrounding relatively low-strain domains (Harland, 1971; Coward, 1984). Understanding such complex behaviours requires the integration of different techniques of strain analysis (Vitale et al., 2007), that have been developed since the classical studies of Ramsay (1967) and Dunnet (1969).

However, strain quantification in tectonites is not straightforward process because the heterogeneous deformation of the rock fabrics could have been achieved by a combination of intra-, trans- and/or inter-granular mechanisms. As the methods usually used in strain quantification studies (e.g. Fry - Normalized Fry, 1979; Hanna and Fry, 1979; Erslev, 1988 and Rf/ $\phi$ - Dunnet, 1969; Lisle, 1977, 1985) have distinct sensitivities to these different mechanisms, they will usually give different strain values to the same rock sample. Although this could be a limitation in strain estimations studies, it provides the opportunity to gain a better understanding of the relative importance of different deformation mechanism. The interpretation of the strain results is thus a priority in structural geology studies.

In this paper the Fry and Rf $/ \phi$ methodologies, either in two and three-dimensions, are used in the Apúlia region (NW Iberian Variscan autochthon) to understand the relation between cleavage and folds in low grade metamorphic quartzites. These Lower Ordovician quartzites 